\title{
Endomysial antibody: is it the best screening test for coeliac disease?
}

\author{
M Ferreira, S Lloyd Davies, M Butler, D Scott, M Clark, P Kumar
}

\begin{abstract}
The sensitivities and specificities of the IgA and IgG antigliadin antibody and the IgA antireticulin antibody have been compared with the recently described endomysial antibody directed against the basement membrane of smooth muscle in monkey oesophagus. One hundred and seventeen patients with adult coeliac disease ( 21 untreated), 84 patients with inflammatory bowel disease, systemic lupus erythematosus and rheumatoid arthritis (comprising the disease control group), 47 normal controls and a miscellaneous group of 29 patients, who were selected because of a positive reticulin staining pattern, were investigated. These results were correlated with the degree of abnormality of the intestinal mucosa in patients with adult coeliac disease. Endomysial antibodies were found in all patients with untreated coeliac disease and subtotal villous atrophy and in $47 \%$ of patients on a non-strict gluten free diet. One patient on a strict gluten free diet was positive and had partial_villous atrophy while all patients in disease control groups were negative. Results were variable with the antireticulin and antigliadin antibodies. Sensitivity and correlation with subtotal villous atrophy in the untreated patients was $100 \%$. It is concluded that the endomysial antibody is superior to other current antibody tests and should be used in preference for the diagnosis of coeliac disease. (Gut 1992; 33: 1633-1637)
\end{abstract}

The 'gold standard' for the diagnosis of coeliac disease remains the jejunal biopsy. Over the last 30 years, however, most workers have been searching for a less invasive test for both screening and diagnostic purposes. Tests looking for circulating antibodies to gluten, gliadin or reticulin, using immunofluorescence or the enzyme linked immunosorbent assay (ELISA) techniques $^{1-13}$ have been considered potential screening tests for coeliac disease. The sensitivities and specificities of these tests have varied from centre to centre but have been improved by using class specific immunoglobulin. ${ }^{1+16}$ This variability has been a drawback to their diagnostic use.

Chorzelski et al $^{17}$ described a new antibody directed against the membrane of smooth muscle bundles of primates. This endomysial antibody was present in patients with dermatitis herpetiformis and coeliac disease. This antibody may be closely related to the reticulin antibody. The antibody titres have been shown to correlate with the severity of the histopathological abnormali- ties in the jejunal mucosa although the numbers of patients investigated are small.

The aim of our study was to compare the sensitivities and specificities of the antigliadin antibody, antireticulin antibody and endomysial antibody using ELISA and immunofluorescent techniques in a variety of patient groups.

\section{Methods}

\section{PATIENTS}

One hundred and seventeen patients with adult coeliac disease (21 untreated, 81 treated with a strict gluten free diet and 15 on a non-strict gluten free diet were studied. The age range was 15-78 years (median age 38 ) and these patients were compared with 47 normal controls (median age 46 years) from the hospital staff population and matched as closely as possible for age and sex with the coeliac population. The diagnosis of coeliac disease was based on the typical histological appearance of the jejunal mucosa followed by an improvement on gluten withdrawal. Eight patients originally diagnosed on histological grounds did not improve on gluten withdrawal but have been included for interest. All 21 untreated patients have had repeat jejunal biopsies which have shown morphological improvement. The disease control group consisted of 21 patients with Crohn's disease (median age 26 years) and 10 patients with ulcerative colitis (median age 40 years); 33 patients with systemic lupus erythematosus (median age 35 years) and 20 patients with rheumatoid arthritis (median age 60 years) were also included as these conditions have an immunological aetiology. Another 29 patients were included as their initial immunofluorescence screen with polyclonal antisera gave a positive reticulin pattern. These sera had been sent to the laboratory for routine screening but their clinical diagnosis was unknown at the time.

All untreated patients with coeliac disease had intestinal biopsies, 14 of 15 patients on a nonstrict gluten free diet and 23 of the 81 patients on a strict gluten free diet also had biopsies. These were performed using a Crosby capsule either alone or barrel loaded on endoscopes and were taken from the duodenojejunal flexure.

Blood was taken from the patients on the day of the jejunal biopsy or within two weeks and aliquots of the sera were stored at $-30^{\circ} \mathrm{C}$. A new aliquot was thawed for each test. Some patients were assayed twice but these specimens were at least three months apart. In total 21 assays were performed on 21 untreated patients, 19 assays on 15 patients on a non-strict gluten free diet and 91 
assays on 81 patients treated with a strict gluten free diet.

The strictness of the gluten free diet was assessed by at least two of the following methods: visual analogue scale, ${ }^{18}$ review by dietitian, and the patients' information to the physician. Patients on an estimated $60-80 \%$ gluten free diet (approximately 3-10 g gluten per day) were considered to be 'non-strict.'

\section{IMMUNOFLUORESCENCE}

This was used for both the endomysial and antireticulin antibody assays. The method described by Beutner et al ${ }^{19}$ was used with minor modifications. Tissue sections (rat kidney for antireticulin antibodies and Marmoset monkey oesophagus for endomysial antibodies were mounted on microscope slides. Serum diluted $1: 2.5$ with phosphate buffered saline was applied to slides which were incubated for 30 minutes at room temperature (positive sera were further diluted), this titre was chosen because no residual staining was seen at this or higher titres. After washing with phosphate buffered saline the sections were covered with 1:20 fluorescein conjugated rabbit anti-human IgA (Dako) for 30 minutes, washed with phosphate buffered saline and examined by fluorescence microscopy. Sera were considered positive if fluorescence was seen at a dilution of $1: 2 \cdot 5$ or greater.

Sections of Marmoset monkey oesophagus were used for the endomysial antibody estimations and compared with the commercially available oesophageal sections (BioDiagnostics, Upton upon Severn). Positive and negative controls were used for each batch and reproducibility of the tests was checked on the same day and on different days.

ENZYME LINKED IMMUNOSORBENT ASSAY (ELISA) Antibodies to gliadin were estimated using the enzyme-linked immunosorbent assay ${ }^{10}$ following modification (Lloyd Davies et al unpublished data). A strongly positive serum was used to produce a standard curve, this serum had been given an arbitrary value of 100 units at a specific dilution (IgG 1:500, IgA 1:100). The IgA and IgG antigliadin antibody distribution within a normal population had been established by comparing absorbances of a large number of samples generated from a blood bank population to the standard curve of the strongly positive serum and a reporting regime established. Studies were carried out on reproducibility during modification of the ELISA, the method was found to be highly reproducible. Negative values were 0-34 units for IgG and 0-9 for IgA; positive values $35-59$ and $10-49$ and strongly positive values were $60+$ or $50+$ respectively.

\section{JEJUNAL MUCOSA}

This was assessed histologically and graded into three broad categories: 'normal' (no inflammation, normal intraepithelial lymphocyte counts, normal villi): 'partial villous atrophy' (mild to moderate villous flattening, an increase in intraepithelial lymphocytes and some crypt
TABLE I Serology results

\begin{tabular}{llllll}
\hline $\begin{array}{l}\text { Patient } \\
\text { groups }\end{array}$ & Assays & $\begin{array}{l}\text { EmA } \\
\text { IgA } \\
\% \text { Positive }\end{array}$ & $\begin{array}{l}\text { ARA } \\
\operatorname{IgA}\end{array}$ & $\begin{array}{l}A G A \\
I g A\end{array}$ & $\begin{array}{l}A G A \\
I g G\end{array}$ \\
\hline $\begin{array}{l}\text { Coeliacs } \\
\text { Untreated }\end{array}$ & 21 & 100 & 90 & 90 & 76 \\
GFD non-strict & 19 & 47 & 47 & 47 & 42 \\
GFD strictt & 91 & 1 & 8 & 11 & 23 \\
Disease controls & 21 & 0 & 0 & 25 & 21 \\
Crohn's & 10 & 0 & 0 & 10 & 10 \\
UC & 33 & 0 & 0 & 6 & 6 \\
SLE & 20 & 0 & 0 & 15 & 10 \\
RA & 29 & 7 & 7 & 17 & 18 \\
Miscellaneous & 47 & 0 & 0 & 15 & 11 \\
Healthy controls & 47 & & & \\
\hline
\end{tabular}

GFD $=$ gluten free diet; ${ }^{\star}=19$ assays on 15 patients; $\dagger=91$ assays on 81 patients; $\mathrm{EmA}=$ endomysial antibody; $\mathrm{ARA}=$ antireticulin antibodies; $\mathrm{AGA}=$ antigliadin antibodies; $\mathrm{UC}=$ ulcerative colitis; $\mathrm{SLE}=$ systemic lupus erythematosus; $\mathrm{RA}=$ rheumatoid arthritis.

hyperplasia): 'Sub-total villous atrophy' (severe villous flattening with crypt hyperplasia, inflammation and increased intraepithelial lymphocytes).

\section{Results}

A comparison was made between positive results for all the assays (Table I).

\section{COELIAC DISEASE}

All 21 patients with untreated coeliac disease had positive endomysial antibody. Both antireticulin and $\operatorname{IgA}$ antigliadin antibodies were found in only $90 \%$ of these patients. Only one patient on a strict gluten free diet had a positive endomysial antibody, but $8 \%$ were positive for antireticulin antibodies and $11 \%$ were positive IgA antigliadin antibodies. As expected the results were intermediate in those patients on a non-strict gluten free diet.

Eight previously untreated patients were followed up after treatment with a gluten free diet and after six months only one patient (on a strict gluten free diet, mentioned above) was positive for endomysial, $\operatorname{IgA}$ and antireticulin antibodies.

\section{DISEASE CONTROLS}

No patients had positive endomysial or antireticulin antibodies. The IgA antigliadin antibodies, however, were positive in $6-25 \%$ of the disease control groups whilst the IgA antigliadin antibodies were positive in $6-21 \%$.

\section{NORMAL CONTROLS}

No positive results were obtained for either endomysial or antireticulin antibodies. Fifteen per cent of patients, however, were positive for IgA antigliadin antibodies and $11 \%$ for IgG antigliadin antibodies.

\section{MISCELLANEOUS CONTROLS}

Only two patients (7\%) were positive for endomysial antibody. One patient had insulin dependent diabetes mellitus and one had thyroiditis. 
TABLE II Biopsy/serology correlation

\begin{tabular}{llll}
\hline $\begin{array}{l}\text { Patient } \\
(n)\end{array}$ & $\begin{array}{l}\text { Patient } \\
(n)\end{array}$ & EmA positive & $\begin{array}{l}\text { IgA ARA } \\
\text { positive }\end{array}$ \\
\hline Untreated (21) & SVA-20 & 20 & 18 \\
Strict GFD (23) & PVA-1 & 1 & 1 \\
PVA-1 & 1 & 0 \\
Non-strict GFD (14) & PVA-9 & 0 & 0 \\
& Normal-5 & 6 & 4 \\
& & 1 & 1 \\
\hline
\end{tabular}

PVA=partial villous atrophy; SVA=sub total villous atrophy; GFD=gluten free diet.

TABLE III Sensitivity/specificity and predictive values for all assays

\begin{tabular}{lclll}
\hline & $\begin{array}{llll}E m A \\
I g A\end{array}$ & $\begin{array}{l}\text { ARA } \\
I g A\end{array}$ & $\begin{array}{l}\text { AGA } \\
I g A\end{array}$ & $\begin{array}{l}\text { AGA } \\
I g G\end{array}$ \\
\hline Sensitivity & 100 & 91 & 91 & 76 \\
Specificity & 99 & 99 & 85 & 88 \\
Positive predictive value & 91 & 91 & 45 & 46 \\
Negative predictive value & 100 & 99 & 99 & 97 \\
\hline
\end{tabular}

For abbreviations see Table I.

CORRELATION OF ANTIBODIES WITH JEJUNAL MORPHOLOGY (Table II).

\section{Coeliac disease}

Untreated patients. Of these 21 patients 20 had subtotal villous atrophy and one had severe partial villous atrophy and all were endomysial antibody positive.

Strict gluten free diet. Twenty three patients had normal mucosa; all were endomysial antibody and antireticulin antibody negative but two patients had positive antigliadin antibodies (IgA, IgG). One patient with partial villous atrophy had a weakly positive endomysial antibody.

Non-strict gluten free diet. In patients on a 'nonstrict' gluten free diet the positive results were as follows: five patients had a normal mucosa and only one patient was positive for endomysial and antireticulin antibodies, nine patients had partial villous atrophy, six were endomysial antibody positive and four were positive for antireticulin antibodies.

\section{SENSITIVITY/SPECIFICITY}

The sensitivity and specificity of each test was calculated from the results and are shown in Table III with the predictive values for the tests.

\section{Discussion}

The description of the endomysial antibody by Chorzelski et al in $1983^{17}$ has reawakened the search to find a less invasive reliable screening test for coeliac disease. The endomysial antibody was initially found in patients with coeliac disease and dermatitis herpetiformis and has been found to have a greater specificity. ${ }^{811} 161720: 22$ It has never been found to be positive in healthy controls ${ }^{1621-23}$ and has so far been negative in patients with Crohn's disease, ulcerative colitis ${ }^{1621-23}$ and in other gastrointestinal diseases. The endomysial antibody therefore promises to be an excellent non-invasive screening test with a high specificity. However, it has not always been shown to have $100 \%$ sensitivity for untreated coeliac disease, as the positivity has varied between 91 and $100 \%$. $^{116}$ Results of patients on gluten free diets have varied from $0 \%$ positivity ${ }^{112223}$ to $67 \cdot 9 \%$. $^{822-24}$

The aim of our study was to compare and contrast the sensitivities and specificities of the endomysial antibody compared with antireticulin and antigliadin antibodies. We measured these antibodies using the immunofluorescent test for the endomysial and antireticulin antibodies and the ELISA test for the antigliadin antibodies. The immunofluorescent test for the antigliadin antibody was not used as it has been shown to be unreliable. Our results show that the antibody was $100 \%$ sensitive for patients with untreated coeliac disease. The antireticulin antibody although not so sensitive, showed a very high degree of specificity. Both the endomysial and IgA antireticulin antibodies showed a positive predictive value for detecting the disease in approximately $91 \%$ of patients; the latter figure for the endomysial antibody is not $100 \%$ as two patients (with insulin independent diabetes mellitus and Hashimoto's thyroiditis disease) were shown to be positive. These patients had no recorded symptoms of malabsorption and have refused further investigation. It is known, however, that there is an increased frequency of coeliac disease in patients with insulin dependent diabetes mellitus ${ }^{2526}$ and autoimmune diseases are also seen with increased frequency in patients with coeliac disease ${ }^{27}$; it is therefore possible that these patients may have coeliac disease.

Our results are not in accordance with those of McMillan et $a l^{28}$ who found that $89 \%$ of their patients with untreated coeliac disease had a positive endomysial antibody (measured by immunofluorescence) compared with $100 \%$ positivity obtained with gliadin $\operatorname{IgA}$ using an ELISA test. The titres of patients' sera used in both tests were not given in their report. We used a titre of $1: 2.5$ for the endomysial antibody immunofluorescence as no residual staining was seen at this titre and with the ELISA there was a definite cut off point between positive and negative. Our IgA antigliadin antibody only showed a $91 \%$ positivity in patients with untreated coeliac disease while the endomysial antibody was $100 \%$ positive.

Rossi et $a l^{29}$ assessed the relationship of the endomysial antibody to the severity of the mucosal lesions. They found that all patients with detectable endomysial antibody at the time of biopsy exhibited the more advanced changes of villous atrophy. Endomysial antibody was not detected in 160 subjects with diarrhoea, 18 of whom had mild villous atrophy. Their conclusion was that endomysial antibody appeared to be specifically correlated to the intestinal histopathology of coeliac disease and did not appear to be a non-specific marker for mucosal atrophy. One of their patients, however, who was initially positive for endomysial antibody, had an intestinal infestation with Giardia lamblia, an 
intestinal biopsy performed after treatment for the parasite showed normal histology and the patient negative endomysial antibody. Volta et $a l^{\text {" }}$ in their recent report noted that some of their patients were endomysial antibody positive although their jejunum had recovered; endomysial antibody was seen at a higher frequency in children rather than adults and in their study the prevalence of $\operatorname{IgA}$ endomysial and antigliadin antibodies were not statistically different. In our non-strict group although six of nine patients with partial villous atrophy were endomysial antibody positive we were surprised to find three patients who were negative. The kinetics of the endomysial antibody are not yet known and it is possible that these patients may not have had a recent ingestion of gluten. Our results, however, were obtained from a predominantly adult population and indicate that endomysial antibody is found in all untreated patients.

The exact nature of the endomysial antibody is still unknown, recently Kárpáti et $a l^{31}$ have observed IgA antibodies from patients with dermatitis herpetiformis that bind to the normal human jejunum. These jejunal antibodies showed similarities to both IgA antireticulin antibodies and endomysial antibody. They showed that the binding of these antibodies to intestinal tissue was comparable with the $\operatorname{IgA}$ deposits seen in small bowel biopsy samples from patients with dermatitis herpetiformis and coeliac disease. 32 In a further study Kárpáti et $a l^{11}$ showed that 13 of 14 untreated children with coeliac disease had jejunal antibodies and only one of 21 were positive after a gluten free diet although $90 \%$ of patients on a gluten challenge showed a reappearance of the jejunal antibodies. This antibody could not be demonstrated in 53 disease control patients with normal jejunal morphology or in three patients with coeliac disease with a selective IgA deficiency. In their studies they simultaneously determined concentrations of antigliadin, endomysial and jejunal antibodies. Using absorption studies with jejunal and antigliadin antibodies they found that jejunal antibodies and antigliadin antibodies were different whereas jejunal antibodies and endomysial antibodies were probably identical. The authors suggested that IgA jejunal antibodies could be the 'target organ related' autoantibody in coeliac disease. A report this year from Kárpáti et $a l^{33}$ further corroborates their suggestion that the endomysial antibody and jejunal antibody are identical.

Hälström et al, however, ${ }^{16}$ was unable to distinguish between IgA antigliadin antibodies reacting with human tissues and endomysial antibodies reacting with monkey oesophagus in his absorption studies. We found that the endomysial antibody was very similar but not identical to the antireticulin antibody shown on rat kidney.

Antigliadin antibodies in our study have again shown that they are not specific for the disease. They were found in all disease control groups as well as in normal controls and the specificity was only slightly improved with the IgA antigliadin antibody. The results are disappointing and reiterate results in previous studies.

We conclude that in our hands the endomysial and antireticulin antibodies are very similar, although the endomysial antibody is more sensitive. The endomysial antibody fluorescence is cleaner and easier to read than the antireticulin antibodies and therefore we suggest that this is the optimum screening test for use within a routine laboratory. Tissue sections are available commercially and actual technique is routine in most immunology laboratories.

We would like to thank Dr A Cunningham of the Institute of Pathology, London Zoo for the donation of Marmoset monkey oesophagus; the Coeliac Trust and the Medical College of St Bartholomew's Hospital. Previously presented in abstract form at the British Society of Gastroenterology, Autumn meeting, September 1991

1 Lancaster-Smith M, Kumar P, Clark ML, Marks J, Johnston PG. Anti-reticulin antibodies in dermatitis herpetiformis and adult coeliac disease. Their relationship to gluten free diet and jejunal histology. $\mathrm{Br}$ f Dermatol 1975;92:37-42.

2 Seah PP, Fry I, Holborrow EJ, Rossiter MA, Doe WF Malgalhaes AF, et al. Anti-reticulin antibody: Incidence and diagnostic significance. Gut 1973; 14: 311-5.

3 Eade OE, Lloyd RS, Lang C, Wright R. IgA and IgG reticulin antibodies in coeliac and non-coeliac patients. Gut 1977; 18: 991-3.

4 Eterman KP, Feltkamp TEW. Antibodies to gluten and reticulin in gastrointestinal diseases. Clin Exp Immunol 1978; 31: 92-9.

5 Ljunghall K, Scheynius A, Forsum U. Circulating reticulin autoantibodies of IgA class in dermatitis herpetiformis. $\mathrm{BrF}$ Dermatol 1979; 100: 173-6.

6 Unsworth DH, Manuel PED, Walker-Smith JA, Campbell JA, Johnston GD, Holborrow EJ. New immunofluorescent blood test for gluten sensitivity. Arch Dis Child 1981; 56: 864-8.

7 Mäki M, Hällström O, Vesikari T, Visakorpori JK. Evaluation of a serum IgA class reticulin antibody test for the detection of childhood coeliac disease. F Pediatr 1984; 105: 901-5.

8 Chorzelski TP, Beutner EH, Sulej J, Chorzewaska H, Jablonska, S, Kumar V, et al. IgA anti-endomysium antibody. A new immunological marker of dermatitis herpetiformis and coeliac disease. Br $\mathcal{F}$ Dermatol $1984 ; 111$ : 395402 .

9 Unsworth DJ, Walker-Smith JA, McCarthy D, Holborrow EJ. Studies on the significance of Rl anti-reticuli antibody associated with gluten sensitivity. Int Arch Allergy Immunol 1985; 76: 47-51.

10 Volta U, Lenzi N, Lazzari R, Cassani F, Collina A, Bianchi $\mathrm{SB}$, et al. Antibodies to gliadin detected by immuno$\mathrm{SB}$, et al. Antibodies to gliadin detected by immunofluorescence and a micro-ELISA method: markers of

11 Kárpáti S, Burgin-Wolff A, Kreig T, Murier M, Stolz W, Braun-Falco O. Binding to human jejunum of serum IgA antibody from children with coeliac disease. Lancet 1990; 336: $1335-8$

12 Dias J, Unsworth DJ, Walker-Smith JA. Anti-gliadin and anti-reticulum antibodies in screening for coeliac disease. Lancet 1987; ii: 157-8.

13 Savilahti E, Perkko M, Kaliso K, Viander M, Vainio E, Reunala T. IgA anti-gliadin antibodies: A marker of mucosal damage in childhood coeliac disease. L ancet 1983; i: 320.

14 Elewaut A, Dacremont G, Robberecht E, Leroy J, De Baets MH. IgA isotyping of anti gliadin antibodies. A possible clue for a less invasive diagnosis of coeliac disease. Clin Chim Acta for a less invasive diagn $183: 285-94$.

15 Scott H, Fausa O, Ek J, Valnes K, Blystad L, Brandtzaeg P. Measurement of serum IgA and IgG activities to dietary antigens. A prospective study of the diagnostic usefulness in adult coeliac disease. Scand f Gastroenterol 1990; 25: 287-92.

16 Hällström O. Comparison of IgA class reticulin and endomysium antibodies in coeliac disease and dermatitis herpetiformis. Gut 1989; 30: 1225-32.

17 Chorzelski TP, Sulej J, Tchorzewski H, Jablonska S, Beutner $\mathrm{EH}$, Kumar V. IgA class endomysium antibodies in dermatitis herpetiformis and coeliac disease. Ann NY Acad Sci 1983; 420: 325-34.

18 Kumar PJ, Clark ML, Dawson A. Adult coeliac disease and low gluten diets. In: Kumar PJ, Walker-Smith JA, eds. Coeliac disease: one hundred vears. Leeds: University of Leeds, 1990; 289-93.

19 Beutner EH, Chorzelski TP, Kumar V, Leonard J, Krasny S. Sensitivity and specificity of IgA class anti-endomysial antibodies for dermatitis herpetiformis and findings relevant to the pathogenic significance. $\mathcal{F} \mathrm{Am}$ Acad Dermatol 1986; to the pathor $464-73$

20 Meurer M, Raff P, Burgin-Wolff A, Chorzelski TP. Circulating IgA class endomysial antibodies in dermatitis herpetiformis: correlation with enteropathy and gluten free diet. $\mathcal{F}$ Invest Dermatol 1985; 84: 453.

21 Kumar V, Hemedinger E, Chorzelski TP, Beutner EH Valeski JE, Kowalewski C. Reticulum and endomysial antibodies in bullous diseases. Comparison of specificity and sensitivity. Arch Dermatol 1987; 123: 1179-82.

22 Kapuscinski A, Zalewski T, Chor/elski TP, Sulej J, Beutner $\mathrm{EH}$, Kumar $\mathrm{V}$, et al. Disease specificity and dynamics of changes in IgA class anti-endomysial antibodies in coeliac disease. 7 Pediatr Gastroenterol Nutr 1987; 6: 529-34. 
23 Kumar V, Beutner EH, Learner A, Jaine N, Chorzelski TP. Comparison of disease specificity of anti-endomysial and anti-gliadin antibodies. In: Beutner EH, Chorzelski TP, Kumar V, eds. Immunopathology of the skin. 3rd ed. New York: 1987

24 Kumar V, Learner A, Valeski JE, Beutner CH, Chorzelski TP, Rossi T. Endomysial antibodies in the diagnosis of coeliac disease and the effect of gluten on antibody titres. Immunol Invest 1989; 18: 533-44.

25 Mäki M, Hällström O, Huupponen T, Vesikari T, Visakorpi $\mathrm{JK}$. Increased prevalence of coeliac disease in diabetes. Arch Dis Child 1984; 52: 739-42.

26 Bonazzi C, Pisi E, Salardi S, Cacciari E. Antigliadin and antireticulin antibodies-coeliac disease and at onset of diabetes. Lancet 1987; ii: 1034.

27 Kumar PJ. The enigma of coeliac disease. Gastroenterology 1985; 89: $214-5$.

28 McMillan SA, Haughton DJ, Biggart JD, Edgar JD, Porter KG, McNeill TA. Predictive value for coeliac disease of antibodies to gliadin, endomysium and jejunum in patients attending for jejunal biopsy. BMF 1991; 303: $1163-5$

29 Rossi TM, Kumar V, Learner A, Heitlinger LA, Tucker N, Fisher J. Relationship of endomysial antibodies to jejunal mucosal pathology: specificity towards both symptomatic and asymptomatic coeliacs. F Pediatr Gastroenterol Nutr 1988; 7: 858-63.

30 Volta U, Molinaro N, Fusconi M, Cassani F, Bianchi FB. IgA Antiendomysial antibody test, a step forward in celiac disease. Dig Dis Sci 1991; 36: 752-6.

31 Kárpáti S, Kosnai I, Török E, Kovacs JB. Immunoglobulin A deficiency in jejunal mucosal of children with dermatitis herpetiformis. F Invest Dermatol 1988; 91: 336-9.

32 Shiner M, Ballad J. Antigen-antibody reactions and jejunal mucosa in childhood coeliac disease after a gluten challenge. Lancet 1972; i: 1202-5.

33 Kárpáti S, Meurer M, Stolz W, Bürgin-Wolff A, Braun-Falco $\mathrm{O}$, Krieg $\mathrm{T}$. Ultrastructural binding sites of endomysium antibodies from sera of patients with dermatitis herpetiformi and coeliac disease. Gut 1992; 33: 191-3. 